\title{
Partial Purification and Resolution of a Thiosulphate-oxidizing System from Thiobacillus A2
}

\author{
By WEI-PING LU AND D. P. KELLY* \\ Department of Environmental Sciences, University of Warwick, Coventry CV4 7AL, U.K.
}

(Received 30 July 1982; revised 2 December 1982)

A crude thiosulphate-oxidizing extract of Thiobacillus A2 has been resolved by ammonium sulphate fractionation and DEAE-Sepharose CL-6B chromatography into fractions containing several components necessary for thiosulphate oxidation and reduction of cytochrome $c$. These components include two distinct $c$-type cytochromes, sulphite :cytochrome $c$ oxidoreductase, rhodanese and enzymes probably responsible for thiosulphate cleavage and sulphane-sulphur oxidation. The complete cytochrome $c$-dependent thiosulphate-oxidizing system could be reconstituted by mixing selected fractions from the column chromatography.

\section{INTRODUCTION}

Despite considerable study over many years, a complete understanding of the mechanism of thiosulphate oxidation to sulphate by thiobacilli has not yet been achieved (Kelly, 1982). In the preceding paper we reported complete thiosulphate oxidation and energy-coupling with high efficiency by crude cell-free preparations from Thiobacillus A2 (Lu \& Kelly, 1983). The principal unresolved problems of the oxidation pathway are the mechanism of the initial 'activation' reaction of thiosulphate and the nature of the enzymes oxidizing the sulphane-sulphur atom of thiosulphate (and probably also of sulphur and sulphide) to sulphite. A number of hypothetical schemes have appeared (for general reviews, see Kelly, 1968, 1978, 1982; Suzuki, 1974; Aleem, 1975), but substantive evidence to confirm these hypotheses, including highly purified enzymes and the demonstration of thiosulphate oxidation by reconstituted enzyme systems in vitro are still lacking except for the terminal conversion of sulphite to sulphate. Our recent work (Lu \& Kelly, 1983) demonstrated that the enzyme system for thiosulphate oxidation was completely soluble (i.e. not sedimented at $130000 \mathrm{~g}$ ) and that membrane material was required only to provide the cytochrome oxidase system for terminal electron transport. The present paper describes the partial purification, resolution and reconstitution of this soluble enzyme system into three major components.

\section{METHODS}

Organism and chemostat culture. Thiobacillus A2 was grown in continuous culture on a medium as described by Lu \& Kelly (1983) except that $200 \mathrm{mM}-\mathrm{Na}_{2} \mathrm{~S}_{2} \mathrm{O}_{3}$ was used in order to maximize biomass production. A chemostat culture was established in a Gallenkamp glass fermenter vessel with a culture volume of $5 \cdot 21$, stirred (1000 r.p.m.) with a direct drive shaft stirrer module and aerated $\left(320 \mathrm{ml} \mathrm{min}^{-1}\right)$ with air containing $1 \%(\mathrm{v} / \mathrm{v}) \mathrm{CO}_{2}$. Temperature was maintained at $30^{\circ} \mathrm{C}$ with an $\mathrm{LH}$ Engineering heater module and $\mathrm{pH}$ was maintained at $\mathrm{pH} 7 \cdot 7$ by automatic titration with $10 \mathrm{M}-\mathrm{NaOH}$ using an $\mathrm{LH}$ Engineering $\mathrm{pH}$ controller. Thiosulphate was completely consumed and was the growth-limiting nutrient, giving about $7 \mathrm{~g}$ dry wt of bacteria $\mathrm{d}^{-1}$ at a dilution rate of $0.06 \mathrm{~h}^{-1}$. The effluent from the chemostat was collected in a flask maintained at $2{ }^{\circ} \mathrm{C}$ and stored at $4{ }^{\circ} \mathrm{C}$ until centrifuged.

Preparation of cell-free extract. Bacteria were sedimented by centrifuging and the cell pellet suspended to about $80 \mathrm{mg}$ dry wt ml-1 in $55 \mathrm{~mm}$-phosphate buffer ( $\mathrm{pH} \mathrm{7.5)}$ Organisms were disrupted by sonication for $5 \mathrm{~min}$ at $30 \mathrm{~s}$ 
intervals in a $100 \mathrm{ml}$ beaker immersed in ice using a $3 / 4^{\prime \prime}(19 \mathrm{~mm})$ probe and maximum power output from a MSE ultrasonic disintegrator. The treated cell suspension was centrifuged at $10000 \mathrm{~g}$ for $15 \mathrm{~min}$ and the supernatant centrifuged at $48000 \mathrm{~g}$ for $30 \mathrm{~min}$ to remove any unbroken cells and large membrane fragments. The resultant supernatant was designated the 'crude extract'. 'Membrane fraction' was prepared as described by Lu \& Kelly (1983).

Enzyme assays. Thiosulphate and sulphite-oxidizing activities were measured polarographically as described by Lu \& Kelly (1983) except that 'membrane fraction' ( $0.5 \mathrm{mg}$ protein) and various amounts of cytochrome $c$ (horse heart III) were added as indicated. Thiosulphate:cytochrome $c$ oxidoreductase, sulphite:cytochrome $c$ oxidoreductase, rhodanese and succinate-oxidizing activity were assayed as described by Lu \& Kelly (1983). $\left[{ }^{35} \mathrm{~S}\right]$ Sulphate production from $\left[{ }^{35} \mathrm{~S}\right]$ thiosulphate was assayed as described by Kelly \& Syrett (1966).

Ammonium sulphate fractionation. Crude extract was fractionated at $4{ }^{\circ} \mathrm{C}$ by the addition of serially increasing amounts of a saturated $(4 \mathrm{M})$ ammonium sulphate solution. In each step the precipitated protein was centrifuged at $17000 \mathrm{~g}$ for $10 \mathrm{~min}$, then dissolved in a small volume of phosphate buffer $(25 \mathrm{mM}, \mathrm{pH} 6.5$ or $55 \mathrm{mM}, \mathrm{pH} 7 \cdot 5)$ and dialysed against the same buffer for $5 \mathrm{~h}$. The supernatant at each step was brought to a higher percentage saturation with saturated ammonium sulphate. The fraction precipitating between 44 and $65 \%$ of saturation with ammonium sulphate was called fraction A65\%.

Gel filtration. Experimental details are provided in the legends to the figures.

$D E A E$-Sepharose CL-6B chromatography. The A65\% fraction ( $25 \mathrm{ml}, 1550 \mathrm{mg}$ protein) was applied to a column $(2.6 \times 16.5 \mathrm{~cm})$ of DEAE-Sepharose $6 \mathrm{~B}$, equilibrated at $2^{\circ} \mathrm{C}$ with $25 \mathrm{~mm}$-phosphate buffer, pH 6.5 , containing $2 \mathrm{mM}$-thiosulphate and eluted stepwise with a total of $1600 \mathrm{ml}$ of the same buffer containing $\mathrm{NaCl}$ at $0 \mathrm{M}, 0.1 \mathrm{M}$, $0.2 \mathrm{M}, 0.3 \mathrm{M}, 0.35 \mathrm{M}$ and $0.4 \mathrm{M}$. Fractions $(18 \mathrm{ml})$ collected at $2{ }^{\circ} \mathrm{C}$ using a flow rate of $105 \mathrm{ml} \mathrm{h}^{-1}$ were monitored for protein, $A_{280}, c$-type cytochrome (by absorbance at $416 \mathrm{~nm}$ ), and sulphite :cytochrome $c$ oxidoreductase. Fractions containing distinct peaks of protein or cytochrome were combined and brought to $63 \%$ saturation with ammonium sulphate. The protein precipitated was collected by centrifugation and dissolved in a small volume of $55 \mathrm{~mm}$-phosphate buffer, $\mathrm{pH} 7 \cdot 4$.

Analytical procedures. Thiosulphate was estimated colorimetrically as described by Kelly et al. (1969). Protein was measured by the Lowry procedure, using crystalline bovine serum albumin as standard.

Materials. Sepharose 4B, Sephacryl 300 Superfine and DEAE-Sepharose CL-6B were from Pharmacia. Cytochrome $c$ (horse heart III), cytochrome oxidase (bovine heart), rhodanese (liver) and catalase (liver) were from Sigma.

\section{RESULTS AND DISCUSSION}

\section{Ammonium sulphate fractionation of the crude extract}

The thiosulphate- and sulphite-oxidizing activities were recovered in the fractions above $44 \%$ of saturation with ammonium sulphate (Table 1). The specific activity of thiosulphate oxidation was increased about fourfold in the A61\% fraction compared with that in the crude extract, and total activity recovered was about $91 \%$. Fractions A $21 \%$ and A $39 \%$ contained cell membrane, because (a) these fractions contained nearly all the succinate-oxidizing activity, which was previously shown to be membrane-bound, and (b) they could also replace the requirement for the 'membrane fraction' for electron transfer to oxygen (Table 1). The rate of thiosulphate oxidation in fraction A61\% was stimulated about tenfold by the addition of horse heart cytochrome $c$. This contrasted with the crude extract, to which addition of cytochrome $c$ had no effect (Table 1). The stimulation could have been due to the loss of a certain amount of specific $c$-type cytochrome during the fractionation, even though the content of $c$-type cytochrome increased from about $1.4 \mathrm{nmol}$ (mg protein $)^{-1}$ in the crude extract to about $2 \mathrm{nmol}(\mathrm{mg} \text { protein })^{-1}$ in fraction $\mathrm{A} 61 \%$. This possibility was supported by the fact that addition of fractions A $21 \%$ and A $39 \%$ to the reaction mixture instead of the membrane fraction (prepared as described by Lu \& Kelly, 1983) showed higher thiosulphate-oxidizing activity in the absence of added horse heart cytochrome $c$. The thiosulphate : cytochrome $c$ oxidoreductase activity of fraction $\mathrm{A} 65 \%$ showed a $K_{\mathrm{m}}$ value of about $200 \mu \mathrm{M}$ for horse heart cytochrome $c$. The fact that a multiplicity of enzymes is involved in this system means, however, that this value might not be highly significant. The A65\% fraction oxidized thiosulphate completely to sulphate. This was demonstrated by the consumption of two moles of oxygen for each thiosulphate oxidized and the demonstration, using thiosulphate labelled with ${ }^{35} \mathrm{~S}$ in either atom, that both the sulphane- and sulphone-sulphur were oxidized to sulphate (Table 2). 


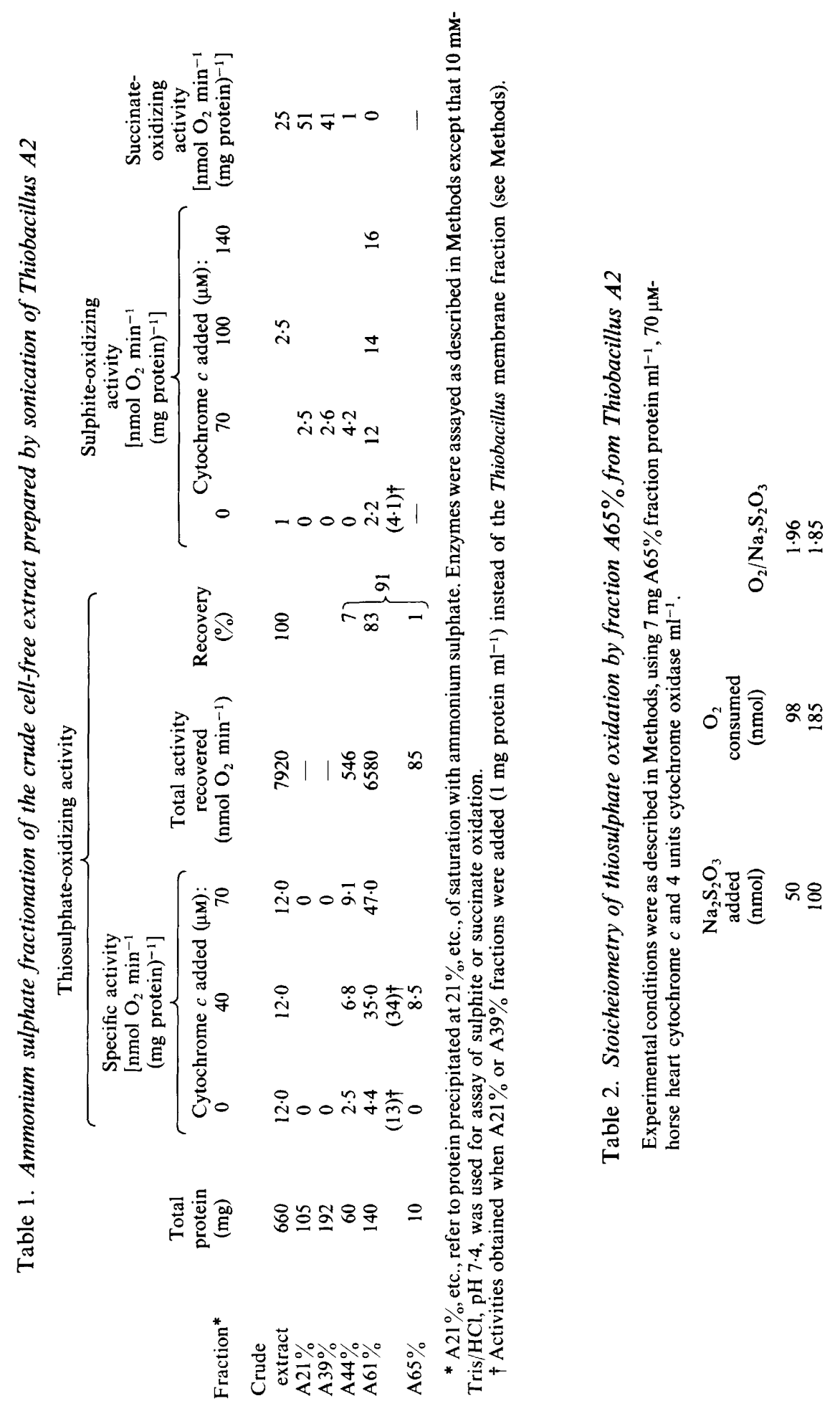




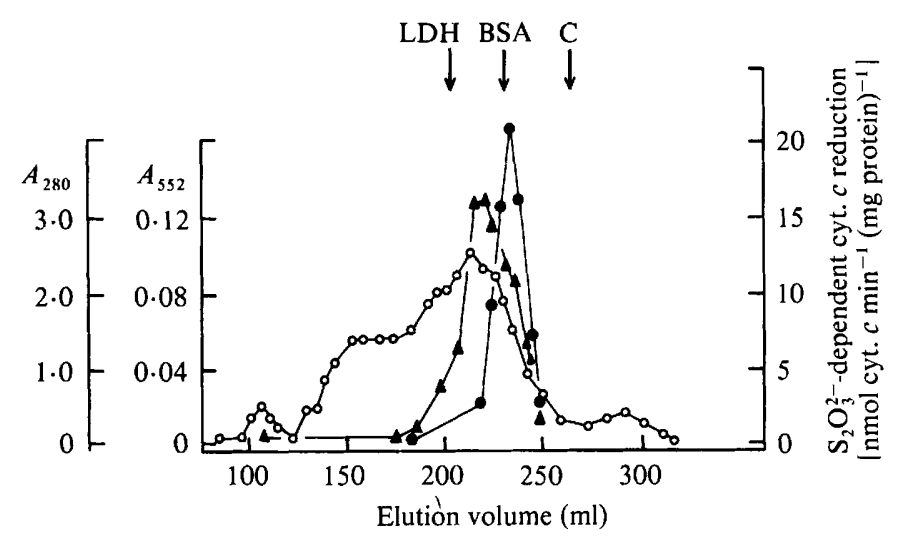

Fig. 1. Gel filtration of the A65\% fraction from Thiobacillus A2 on Sepharose CL-4B. The sample (92 mg protein) was applied to a column of Sepharose CL-4B $(2.2 \times 78 \mathrm{~cm})$ equilibrated with $10 \mathrm{~mm}-$ Tris/ $\mathrm{HCl}$ buffer, $\mathrm{pH} 7 \cdot 4$, and eluted with the same buffer. Fractions $(4.8 \mathrm{ml})$ were collected at a flow rate of $19.5 \mathrm{ml} \mathrm{h}^{-1}$ at $4{ }^{\circ} \mathrm{C}$ and analysed for protein, $A_{280}(O), A_{552}(\Delta)$ and activity of thiosulphatedependent cytochrome $c$ reduction (O) as described in Methods. The column was calibrated using commercial lactate dehydrogenase (LDH, $M_{\mathrm{r}} 140000 ; 45 \mathrm{mg}$ ), bovine serum albumin $\left(\mathrm{BSA}, M_{\mathrm{r}} 66000\right.$; $10 \mathrm{mg})$ and horse heart cytochrome $c\left(\mathrm{C}, M_{\mathrm{r}} 12384 ; 5 \mathrm{mg}\right)$, chromatographed under identical conditions and eluted in the fractions indicated by the arrows. $A_{280}$ in the first $175 \mathrm{ml}$ of eluate was due to nucleic acid, as insignificant protein eluted in these fractions. Protein and $A_{280}$ elution profiles were coincident between $175-250 \mathrm{ml}$ of eluate.

\section{Gel filtration of the thiosulphate-oxidizing system precipitated by ammonium sulphate between 44 and $65 \%$ of saturation ( $A 65 \%$ )}

Passage of fraction A65\% down a column of Sepharose CL-4B or Sephacryl-300 Superfine yielded similar elution patterns (Figs 1 and 2$)$ with one main peak of protein $\left(A_{280}\right)$ with which a peak of $c$-type cytochrome coincided. The peak of thiosulphate : cytochrome $c$ oxidoreductase activity, however, eluted in fractions slightly behind this main peak (Figs 1 and 2). These results indicate that little resolution of the complex mixture of enzymes necessary for thiosulphate oxidation by the $\mathrm{A} 65 \%$ fraction had been achieved, although the complex was partly resolved from the bulk protein of the preparation.

\section{Resolution of the thiosulphate-oxidizing system into three main fractions by DEAE-Sepharose $C L-6 B$ chromatography}

Chromatography of fraction A65\% on a column of DEAE-Sepharose CL-6B yielded seven distinct peaks with absorbance at $280 \mathrm{~nm}$ or $416 \mathrm{~nm}$ (Fig. 3). The first and last of these (0 $\mathrm{M}$ and $0.4 \mathrm{M}-\mathrm{NaCl}$ ) contained little protein when analysed by the Lowry procedure and were not further studied. The $0 \cdot 1 \mathrm{M}-\mathrm{NaCl}$ fraction contained no detectable cytochrome, but $c$-type cytochrome ( $A_{416}$ and characteristic 550-552 $\mathrm{nm}$ absorbance) was present in the other four peak fractions. The fractions with $0.1 \mathrm{M}$ and $0.2 \mathrm{M}-\mathrm{NaCl}$ had a greenish colour. The $0.35 \mathrm{M}-\mathrm{NaCl}$ eluate was resolved into two parts: the first $(0.35 \mathrm{M}-\mathrm{I})$ contained all the sulphite:cytochrome $c$ oxidoreductase activity and the second $(0 \cdot 35 \mathrm{M}$-II) mainly consisted of $c$-type cytochrome.

None of the fractions alone showed thiosulphate:cytochrome $c$ oxidoreductase activity (Table 3). This activity was, however, recovered when the $0.1 \mathrm{M}$ and $0.35 \mathrm{M}-\mathrm{I} \mathrm{NaCl}$ fractions were mixed. The $0 \cdot 2 \mathrm{M}-\mathrm{NaCl}$ could replace the $0 \cdot 1 \mathrm{M}-\mathrm{NaCl}$ fraction, but gave lower activity. Activity of the $0.35 \mathrm{M}-\mathrm{I}$ fraction with either the $0.1 \mathrm{M}$ or the $0.2 \mathrm{M}-\mathrm{NaCl}$ fraction was stimulated about fivefold by the addition of the $0.35 \mathrm{M}-\mathrm{II} \mathrm{NaCl}$ fraction. Boiling the $0.35 \mathrm{M}$-II fraction destroyed the stimulatory activity. These results demonstrate that a number of components were necessary for the expression of thiosulphate : cytochrome $c$ oxidoreductase activity. Thiosulphate-oxidizing activity could also be measured polarographically using reconstituted mixtures 


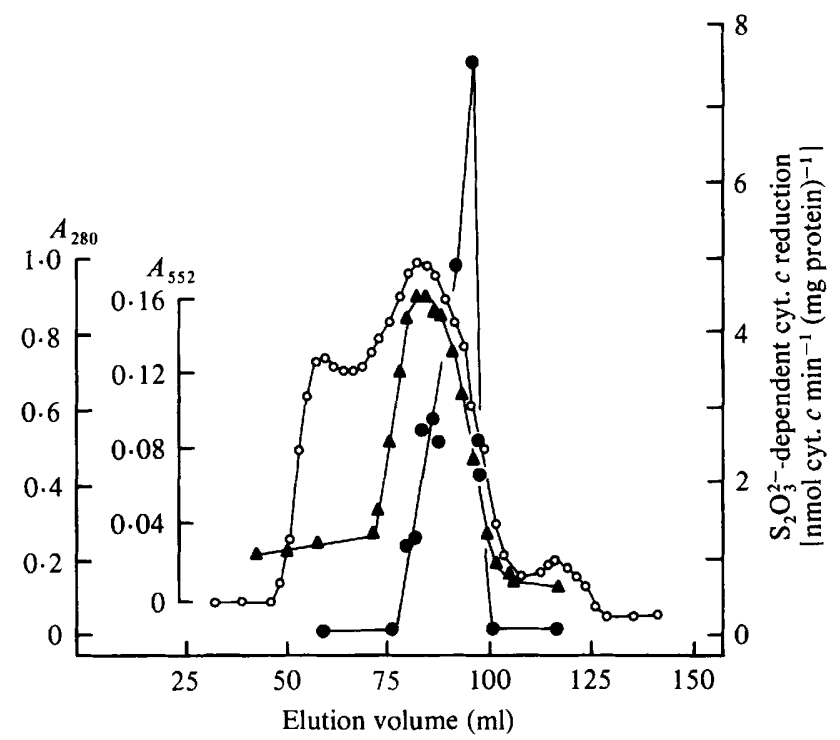

Fig. 2. Gel filtration of the A65\% fraction from Thiobacillus A2 on Sephacryl S-300 Superfine. The sample $(1 \mathrm{ml}$ containing $65 \mathrm{mg}$ protein and $5 \mu$ l glycerol $)$ was applied to a column $(1.6 \times 86 \mathrm{~cm})$ equilibrated with $20 \mathrm{~mm}$-Tris $/ \mathrm{HCl}$ buffer, $\mathrm{pH} 7 \cdot 2$, and eluted with the same buffer. Fractions $(2 \cdot 2 \mathrm{ml})$ were collected at $7.8 \mathrm{ml} \mathrm{h}^{-1}$ at $4{ }^{\circ} \mathrm{C}$. Measurements were made of $A_{280}(O), A_{552}(A)$ and thiosulphatedependent cytochrome $c$ reduction (O).

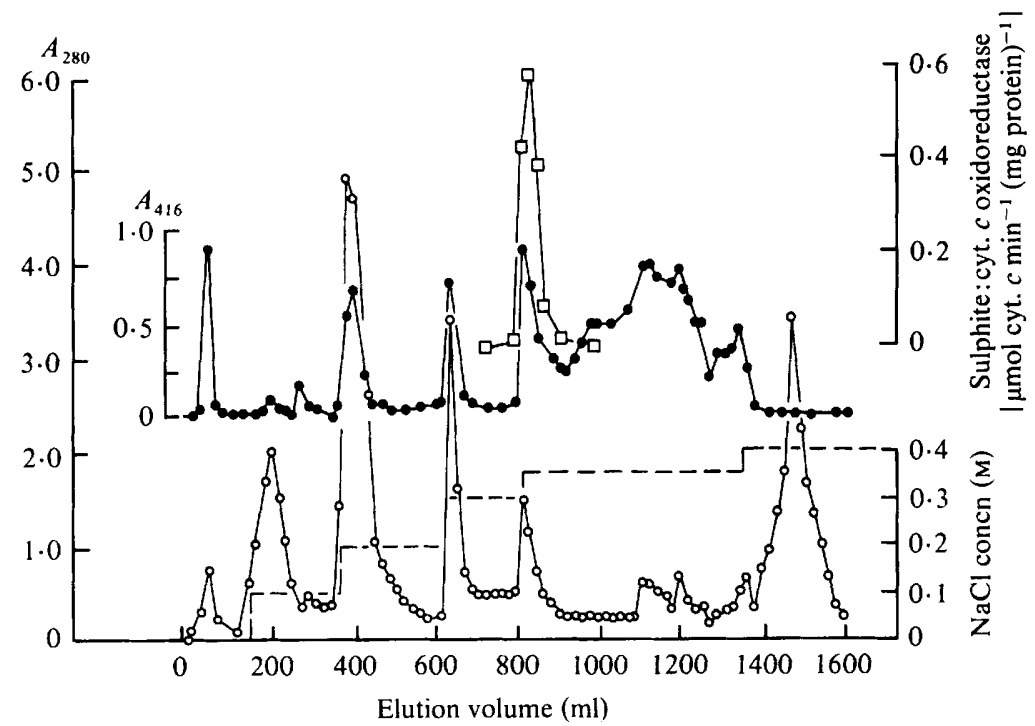

Fig. 3. Fractionation of the A65\% fraction from Thiobacillus A2 on DEAE-Sepharose CL-6B. The chromatography was performed as described in Methods with stepwise elution with increasing concentration of $\mathrm{NaCl}$ in Tris/ $\mathrm{HCl}$ buffer. $\mathrm{NaCl}$ concentration is indicated (---) for each step. Fractions were assayed for $A_{280}(O), A_{416}(O)$ and sulphite :cytochrome $c$ oxidoreductase $(\square)$.

of these fractions. Oxygen uptake was observed when a mixture of the $0.1 \mathrm{M}, 0.35 \mathrm{M}-\mathrm{I}$ and $0.35 \mathrm{M}$ II fractions were supplied with thiosulphate in the presence of horse heart cytochrome $c$ and either bovine cytochrome oxidase or Thiobacillus A2 'membrane fraction'. Oxygen was 
Table 3. Reconstitution of thiosulphate : cytochrome $c$ oxidoreductase activity using fractions from the A65\% fraction of Thiobacillus A2 separated by DEAE-Sepharose CL-6B chromatography

\begin{tabular}{|c|c|c|c|c|c|c|}
\hline \multicolumn{5}{|c|}{ Amount of protein per assay (mg) } & \multirow{3}{*}{$\begin{array}{l}\text { Cytochrome } c \\
\text { reduced } \\
\left(\mathrm{nmol} \mathrm{min}^{-1}\right)\end{array}$} & \multirow{3}{*}{$\begin{array}{c}\text { Specific activity } \dagger \\
\text { [nmol cytochrome } c \text { reduced } \\
\left.\min ^{-1}(\mathrm{mg} \text { protein })^{-1}\right]\end{array}$} \\
\hline \multicolumn{5}{|c|}{ Fraction(s) assayed*: } & & \\
\hline $0.1 \mathrm{M}$ & $0.2 \mathrm{M}$ & $0.3 \mathrm{M}$ & $0.35 \mathrm{M}(\mathrm{I})$ & $0.35 \mathrm{M}$ (II) & & \\
\hline 1.64 & & & & & 0 & 0 \\
\hline & $2 \cdot 4$ & & & & 0 & 0 \\
\hline & & $2 \cdot 7$ & & & 0 & 0 \\
\hline & & & $1 \cdot 04$ & & 0 & 0 \\
\hline & & & & 0.6 & 0 & 0 \\
\hline 1.64 & & & 1.04 & & $5 \cdot 3$ & $2 \cdot 0$ \\
\hline 1.64 & & & $1 \cdot 04$ & $0 \cdot 3$ & $25 \cdot 0$ & $10 \cdot 0$ \\
\hline 1.64 & & & & $0 \cdot 3$ & 0 & 0 \\
\hline & & & 1.04 & $0 \cdot 3$ & 0 & 0 \\
\hline & $2 \cdot 4$ & & 1.04 & & 1.8 & 0.5 \\
\hline & $2 \cdot 4$ & & $1 \cdot 04$ & $0 \cdot 3$ & $13 \cdot 0$ & $5 \cdot 8$ \\
\hline & & $2 \cdot 7$ & $1 \cdot 04$ & & 0 & $\mathbf{0}$ \\
\hline 1.64 & & $2 \cdot 7$ & 1.04 & & $4 \cdot 5$ & 0.8 \\
\hline 1.64 & $2 \cdot 4$ & & $1 \cdot 04$ & & $5 \cdot 3$ & 0.7 \\
\hline
\end{tabular}

* The fractions are designated by the molarity of $\mathrm{NaCl}$ with which they were eluted.

† Enzyme activity was measured as described in Methods, using $70 \mu \mathrm{M}$-horse heart cytochrome $c, 90 \mathrm{mM}$-Tris/ $\mathrm{HCl}, \mathrm{pH} 7 \cdot 4$, and amounts of protein as indicated. Specific activity is expressed relative to the total protein added in the various fractions.

consumed at about $9 \mathrm{nmol} \min ^{-1}(\mathrm{mg} \text { protein })^{-1}$, calculated only for the protein added in the three $\mathrm{NaCl}$ fractions. This oxidation rate would require cytochrome $c$ reduction and reoxidation at a rate of $36 \mathrm{nmol} \mathrm{min} \mathrm{m}^{-1}$ (mg protein) $)^{-1}$, or rather more than was observed spectrophotometrically (Table 3). The reaction mixture contained only $70 \mu \mathrm{M}$-cytochrome $c$ (or only one-third of that for the $K_{\mathrm{m}}$ value), so oxidation could have been stimulated when complete electron transfer to oxygen was possible.

\section{Separation of two cytochrome c components}

Two distinct cytochrome $c$ spectra were observed in the different $\mathrm{NaCl}$ fractions (Table 4). One was that of the predominant cytochrome $c_{552}$, which was present largely in the oxidized form in fractions $0.35 \mathrm{M}-\mathrm{I}$ and $0.35 \mathrm{M}-\mathrm{II}$, and was rapidly reduced by sulphite when the $0.35 \mathrm{M}-\mathrm{I}$ fraction was present. The other was cytochrome $c_{550}$, which was mainly present in the $0 \cdot 2 \mathrm{M}$ $\mathrm{NaCl}$ fraction. This was always recovered in the reduced form, presumably because of the presence of thiosulphate as an enzyme protector in the eluate. The existence of cytochrome $c_{550}$ in the crude extract and A65\% fraction was masked by the intense absorbance of cytochrome $c_{552}$. Two types of cytochrome $c$ (550 and $551 \mathrm{~nm}$ maxima) were also purified from $T$. novellus (Yamanaka et al., 1971, 1981).

\section{Distribution of enzyme activities among the fractions from $D E A E-S e p h a r o s e C L-6 B$ chromatography}

Thiosulphate :cytochrome $c$ oxidoreductase activity in mixtures of the $0.35 \mathrm{M}-\mathrm{I}, 0.35 \mathrm{M}$-II and either the $0.1 \mathrm{M}$ or $0.2 \mathrm{M}-\mathrm{NaCl}$ fractions (Table 3) always showed a lag and acceleration phase of about $2 \mathrm{~min}$ if the $0 \cdot 1 \mathrm{M}$ or $0.2 \mathrm{M}-\mathrm{NaCl}$ fraction was the component added to initiate the assay. This implied that these two fractions contained an enzyme or enzymes required for the initial attack on thiosulphate, and that this activity was initially rate-limiting. It is likely (Kelly, 1982) that this initial step is the cleavage of thiosulphate to sulphite and a sulphane-sulphur moiety. Enzymes implicated as possible cleavage enzymes include rhodanese (Silver \& Kelly, 1976; Kelly, 1982). 
Table 4. Separation of two types of cytochrome c during DEAE-Sepharose CL-6B chromatography of the $A 65 \%$ fraction from Thiobacillus $A 2$

\begin{tabular}{|c|c|c|c|c|}
\hline \multirow[b]{2}{*}{$\begin{array}{l}\text { Fraction } \\
\text { assayed }\end{array}$} & \multicolumn{3}{|c|}{$\begin{array}{l}\text { Absorption maxima* } \\
\text { in fractions }(\mathrm{nm})\end{array}$} & \multirow[b]{2}{*}{$\begin{array}{c}\text { Concentration } \dagger \\
{\left[\mathrm{nmol}(\mathrm{mg} \text { protein })^{-1}\right]}\end{array}$} \\
\hline & $\alpha$ & $\beta$ & $\gamma$ & \\
\hline $0 \mathrm{M}-\mathrm{NaCl}$ & 550 & & $415(412)$ & ND \\
\hline $0.2 \mathrm{M}-\mathrm{NaCl}$ & 550 & 522 & 416 & 0.4 \\
\hline $0.35 \mathrm{M}-\mathrm{NaCl}(\mathrm{I})$ & 552 & 522 & $418(410)$ & $3 \cdot 0$ \\
\hline $0.35 \mathrm{~m}-\mathrm{NaCl}$ (II) & 552 & 522 & $418(410)$ & $9 \cdot 0$ \\
\hline
\end{tabular}

* Reduced cytochrome absorbance maxima were determined after reduction with dithionite. Oxidized peaks for the $\gamma$ bands are given in parenthesis.

+ Cytochrome $c$ concentration in the fractions was calculated as the reduced minus oxidized absorbance using a millimolar extinction coefficient of 28 , and expressed relative to the total protein content of the fraction. ND, Not determined.

Table 5. Rhodanese activity in the fractions from DEAE-Sepharose CL-6B chromatography of the $A 65 \%$ fraction

Rhodanese activity was assayed as described in Methods.

\begin{tabular}{|c|c|}
\hline & Thiocyanate formed \\
\hline
\end{tabular}

$\begin{array}{lr}\mathrm{A} 65 \% & 270 \\ 0 \cdot 1 \mathrm{M}-\mathrm{NaCl} & 420 \\ 0 \cdot 2 \mathrm{M}-\mathrm{NaCl} & 130 \\ 0 \cdot 3 \mathrm{M}-\mathrm{NaCl} & 100 \\ 0 \cdot 35 \mathrm{M}-\mathrm{NaCl} \text { (I) } & 0 \\ 0 \cdot 35 \mathrm{M}-\mathrm{NaCl} \text { (II) } & 0 \\ \text { Catalase (bovine liver) } & 1500 \\ \text { Rhodanese (bovine liver) } & 1600\end{array}$

Table 6. Separation of sulphite : cytochrome c oxidoreductase during chromatography of the $A 65 \%$ fraction on DEAE-Sepharose CL-6B

Experimental conditions were as described in Methods and in Fig. 2, except that $35 \mu \mathrm{M}$-horse heart

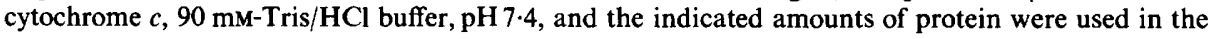
assay.

\begin{tabular}{lcc}
\multicolumn{1}{c}{ Fraction assayed } & $\begin{array}{c}\text { Amount of } \\
\text { protein in assay } \\
(\mathrm{mg})\end{array}$ & $\begin{array}{c}\text { Specific activity } \\
{[\mathrm{nmol} \text { cytochrome } c \text { reduced }} \\
\mathrm{min}^{-1}(\mathrm{mg} \text { protein })^{-1} \text { ] }\end{array}$ \\
$\mathrm{A} 65 \%$ & $0 \cdot 30$ & 110 \\
$0 \cdot 2 \mathrm{M}-\mathrm{NaCl}$ & $0 \cdot 24$ & 4 \\
$0 \cdot 3 \mathrm{M}-\mathrm{NaCl}$ & $1 \cdot 65$ & 2 \\
$0 \cdot 35 \mathrm{M}-\mathrm{NaCl}(\mathrm{I})$ & $0 \cdot 10$ & 1200 \\
$0 \cdot 35 \mathrm{M}-\mathrm{NaCl}(\mathrm{II})$ & $0 \cdot 15$ & 7 \\
$0 \cdot 35 \mathrm{M}-\mathrm{NaCl}(\mathrm{I}+\mathrm{II})$ & $0 \cdot 1+0.05$ & 1500
\end{tabular}

Rhodanese was present at high activity in the $0 \cdot 1 \mathrm{M}-\mathrm{NaCl}$ fraction and to a lesser extent in the $0.2 \mathrm{M}$ fraction (Table 5). Addition of liver rhodanese instead of the $0.1 \mathrm{M}-\mathrm{NaCl}$ fraction in the assay mixture with the $0.35 \mathrm{M}-\mathrm{I}$ and $0.35 \mathrm{M}$-II fractions (as in Table 3) did not, however, give any thiosulphate:cytochrome $c$ oxidoreductase activity. Pure catalase also exhibited rhodanese activity (Table 5), but it could not replace the $0 \cdot 1 \mathrm{M} \cdot \mathrm{NaCl}$ fraction either. The cleaving enzyme in this fraction is thus either not rhodanese, or the activity requires enzymes or cofactors other 


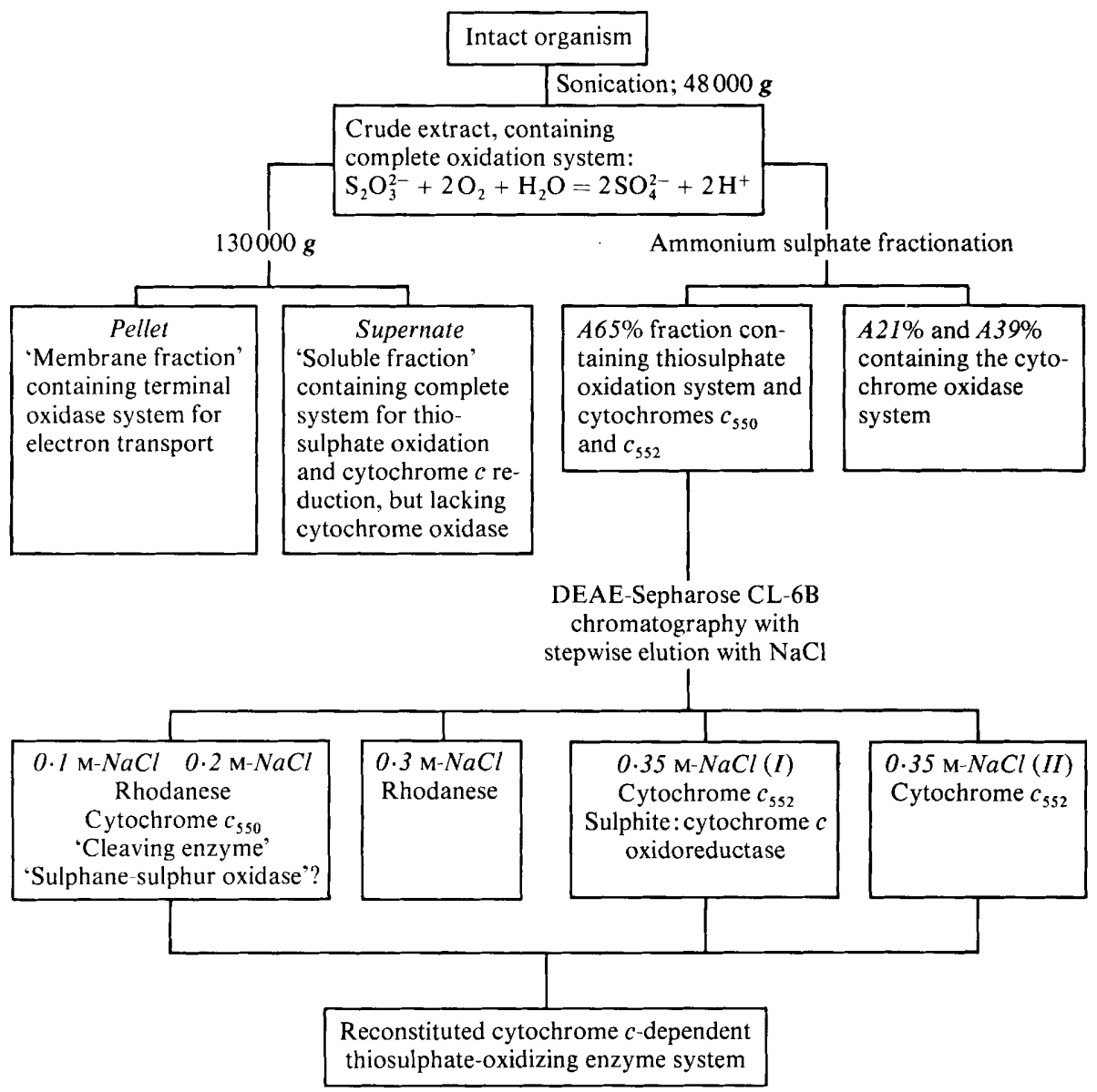

Fig. 4. Summary of the fractionation procedure employed with the cell-free thiosulphate-oxidizing system from Thiobacillus A2.

than rhodanese which are provided by the $0 \cdot 1 \mathrm{M}-\mathrm{NaCl}$ fraction. The location of the enzyme or enzymes catalysing the oxidation of sulphane-sulphur to sulphite has not yet been established, but the complete absence of absorbance in the $590 \mathrm{~nm}$ region in the $0 \cdot 1 \mathrm{M}$ and $0.2 \mathrm{M}-\mathrm{NaCl}$ fractions suggests that they did not contain a sirohaem sulphite reductase of the kind found in $T$. denitrificans, that might in vivo act as a sulphane-oxidase (Schedel \& Trüper, 1979; Kelly, 1982).

The specific activity of sulphite : cytochrome $c$ oxidoreductase was increased about tenfold after chromatography and was recovered in the $0.35 \mathrm{M}-\mathrm{I}$ fraction (Table 6). Activity was further enhanced by addition of the $0 \cdot 35 \mathrm{M}$-II fraction (Table 6). The latter stimulation may reflect improved catalysis of the reaction by the additional Thiobacillus cytochrome $c$.

\section{Conclusions}

This is the first time that a cell-free thiosulphate-oxidizing system from a thiobacillus has been resolved into distinct fractions and then reconstituted from those fractions. The fractionation so far achieved is summarized in Fig. 4. These fractions are, however, still relatively crude and the total number and nature of the enzymes involved is not yet known. The system catalysing the oxidation of sulphane-sulphur to sulphite has clearly survived the fractionation procedure so far, and it is hoped that further purification of the $0.1 \mathrm{M}$ and $0.2 \mathrm{M}-\mathrm{NaCl}$ fractions from DEAESepharose chromatography may enable unequivocal identification of the enzymes and kind of 
reactions involved in the initial metabolism of thiosulphate, and the oxidation of sulphanesulphur.

We are grateful to Dr Mark Woodland for advice and assistance, Dr Ann Wood for discussion and Mrs Dorothy Sanders for technical assistance. This work was made possible by financial support from the Government of the People's Republic of China, the British Council and the SERC.

\section{REFERENCES}

ALEEM, M. I. H. (1975). Biochemical reaction mechanisms in sulfur oxidation by chemosynthetic bacteria. Plant and Soil 43, 587-607.

KeLLY, D. P. (1968). Biochemistry of oxidation of inorganic sulphur compounds by microorganisms. Australian Journal of Science 31, 165-173.

KELLY, D. P. (1978). Bioenergetics of chemolithotrophic bacteria. In Companion to Microbiology, pp. 363-386. Edited by A. T. Bull \& P. M. Meadow. London: Longman.

KELLY, D. P. (1982). Biochemistry of the chemolithotrophic oxidation of inorganic sulphur. Philosophical Transactions of the Royal Society B298, 499-528.

KeLLY, D. P. \& SYRETT, P. J. (1966). [ ${ }^{35}$ S]Thiosulphate oxidation by Thiobacillus Strain C. Biochemical Journal 98, 537-545.

Kelly, D. P., Chambers, L. A. \& Trudinger, P. A. (1969). Cyanolysis and spectrophotometric estimation of trithionate in mixture with thiosulfate and tetrathionate. Analytical Chemistry 41, 898-901.

LU, W.-P. \& Kelly, D. P. (1983). Thiosulphate oxidation, electron transport and phosphorylation in cell-free systems from Thiobacillus A2. Journal of General Microbiology 129, 1661-1671.
SCHEDEL, M. \& TRÜPER, H. G. (1979). Purification of Thiobacillus denitrificans siroheme sulfite reductase and investigation of some molecular and catalytic properties. Biochimica et biophysica acta 568, 454 467.

Silver, M. \& Kelly, D. P. (1976). Rhodanese from Thiobacillus A2: catalysis of reactions of thiosulphate with dihydrolipoate and dihydrolipoamide. Journal of General Microbiology 97, 277-284.

SUZUKI, I. (1974). Mechanisms of inorganic oxidation and energy coupling. Annual Review of Microbiology 28, 85-101.

Yamanaka, T., Takenami, S., Akiyama, N. \& OKUNUKI, K. (1971). Purification and properties of cytochrome C-550 and cytochrome C-551, derived from the facultative chemoautotroph, Thiobacillus novellus. Journal of Biochemistry 70, 349-358.

YamanakA, T., YoshiokA, T. \& Kimura, K. (1981). Purification of sulphite :cytochrome $c$ reductase of Thiobacillus novellus and the reconstitution of its sulphite oxidase system with the purified constituents. Plant and Cell Physiology 22, 613-622. 